\title{
The effects of the creative dance on the analysis of fugue
}

\author{
Peyruze Rana Şimşek ${ }^{1 a}$ and Sermin Bilen ${ }^{2}$ \\ ${ }^{1}$ Res. Assist. University of Dokuz Eylul Buca Faculty of Education Music Education Department \\ Buca Izmir 35150, TURKEY \\ ${ }^{2}$ Assist. Prof. Dr. University of Dokuz Eylul Buca Faculty of Education Music Education Department \\ Buca Izmir 35150, TURKEY
}

\begin{abstract}
Fugue form which can be acknowledged as peak point of polyphonic notation perceptivity is one of the most important of fugal forms. It can be thought that the analysis of fugue is tougher than the analysis of other musical forms. Thus, it is considered that creative dance which forms the basis of "Play, Dance and Music" course would provide benefit on fugue analysis. In this context, problem sentence of study is: Is there a positive effect of creative dance on the analysis of fugue? This study has been carried out in the 2014- 2015 education year on the fourthyear Music Education 12 major students in the Department of Education of Fine Arts and in Dokuz Eylul University, Buca Faculty of Education. The pretest-posttest model has been utilized. The research data has been analysed with the Mann-Whitney U Test.The results of the research have shown that creative dancing activities have a meaningful effect on the analysis of fugue $(\mathrm{p}<0.05)$.
\end{abstract}

Keywords. Play-dance-music; creative dance; musical forms; fugue

\section{Introduction}

Learning through living helps that information is permanent. One of the most important focus in education is the students are extracted from the only listener position and they can move their body, spirit and emotions and learning by experiences.

Traditional education separates senses out off intelligence and focus on only some of the features of intelligence. There is a very delicate relationship between knowing and feeling. How we feel is closely related to what we think and what we know [13].

We need the language of feelings to express what we perceive. This is one of the functions of art. Fields of art can be liberate creative forces.

\footnotetext{
${ }^{a}$ Corresponding author: peyruze.simsek@deu.edu.tr
} 
Dance holds an important place among fields of art and is a means of expressions as important as words and writings. It represents the artistic dimension of communication. It can use as an educational tool,also; it contributes to educating the students who are compatible, aesthetic, creative and collaborative. It can be thought that feeling through movements will contribute to individual's social, emotional, personal and physical progress.

It is expected that qualified music teachers can use body language effectively, express themselves musically and be individuals who are equipped and aesthetics. Thus, they will be able to improve their students musical expressions and aesthetics perceptions. For this, it can be benefited from creative dance that can be considered the most important means using the body language.

Dance art can classify in two categories: Performance oriented dances for audience and participation oriented dances [7]. Creative dance is in second category. Rudolf van Laban is pioneer in the development of creative dance. This type of dance allows individuals are able to express themselves freely. It aims individuals communicate benefiting from movements and release their emotions and personal expressions without hesitation.

Creative dance has common elements with professional dance, but it is different in terms of process. Whereas professional dance focus on techniques, skills and product, creative dance focus on creation, subjectivity and imagination [8].

The creative dance can be considered one of the best ways of understanding music, because it provides that the individuals can use their body as a means of musical expressions. This perceptivity has been a basis of E. J. Dalcroze's music education methodology. Dalcroze can be considered as the pioneer of the idea of collaboration of music and body movement and he has asserted that the musical perception capacity can be developed by benefiting from physical movements. This is the coordination among movement, dance and music is used as means of musical understanding.

The coordination among music courses contributes that learning is consolidated and the creative dance can concretize abstract notions. In view of this power of creative dance, it is considered that creative dance can be used as a means of learning theoretical music courses such as Harmony and Musical Forms. It has been grounded on the idea that creative dance activities can contribute to Musical Forms course in this study. It has been derived from the thought the coordination between Play, Dance and Music and Musical Forms courses can facilitate analysis of complicated musical works.

Fugue form which can be acknowledged as peak point of polyphonic notation perceptivity is one of the most important of fugal forms. Harmonic and formal analysis of fugue form which is substantial in terms of diversifying a musical expression is important in terms of understanding the art of counterpoint. In order to perform the fugue form properly, it must be analysed completely. It can be thought that the analysis of fugue is tougher than the analysis of other musical forms and students can overcome this difficulty, if it is provided coordination between relevant courses.

Thus, it is considered that creative dance which forms the basis of "Play, Dance and Music" course would provide benefit on fugue analysis. In this context, problem sentence of study is: Is there a positive effect of creative dance on the analysis of fugue? The aim of the study is to research the effect of creative dance on the analysis of fugue. It can be thought this study is important due to enable to educating more qualified music teachers by offering a different perspective to music education departments. 


\section{Method}

This study has been carried out in the 2014-2015 education year on the fourth-year Music Education 12 major students in the Department of Education of Fine Arts and in Dokuz Eylul University, Buca Faculty of Education. The pretest-posttest model has been utilized. The research data has been analysed with Mann-Whitney U test.

Processes have been performed in this order:

- The analysis of J.S. BACH's fugue notes has been given as pre-test.

- 6 students who have randomly selected from 12 students have formed the experimental group and the others have formed the control group.

- The four hour course about analysis of fugue has been studied as theoretically with two groups.

- Additionally, the eight hour course has been studied with experimental group and J. S. BACH's another fugue has been transferred to creative dance choreography by this group.

- The analysis of fugue notes that has been carried out as pretest has been given as posttest.

\section{Results}

The results of Mann-Whitney U test has shown below.

Table 1. Descriptive statistics

\begin{tabular}{|c|c|c|c|c|c|c|}
\hline \multirow[t]{2}{*}{ Group } & \multicolumn{3}{|c|}{ Pretest } & \multicolumn{3}{|c|}{ Posttest } \\
\hline & $\mathrm{N}$ & $X$ & $\mathrm{~S}$ & $\mathrm{~N}$ & $X$ & $\mathrm{~S}$ \\
\hline \multirow[t]{2}{*}{ Experimental Group } & & 2 & & 6 & 57 & \\
\hline & \multicolumn{3}{|c|}{2,529} & \multicolumn{3}{|c|}{18,654} \\
\hline \multirow[t]{2}{*}{ Control Group } & 6 & 6,666 & & & 20,500 & \\
\hline & \multicolumn{3}{|c|}{5,125} & \multicolumn{3}{|c|}{16,269} \\
\hline
\end{tabular}

Table 2. Mann-Whitney U test statistics

\begin{tabular}{llll}
\hline & Pretest & Posttest & Difference \\
\hline Mann-Whitney U & 7,000 & 2,500 & 1,000 \\
Wilcoxon W & 28,000 & 23,5000 & 22,000 \\
Z & $-1,800$ & $-2,486$ & $-2,727$ \\
Asymp. Sig. (2-tailed) &, 072 &, 013 &, 006 \\
Exact Sig. [2*(1-tailed Sig.)] &, $093^{\mathrm{b}}$ &, $009^{\mathrm{b}}$ &, $004^{\mathrm{b}}$ \\
\hline
\end{tabular}

According to the results of Mann-Whitney U Test, there is no significant difference between the experimental and the control group's pre-test scores $(\mathrm{p}=0.07>0.05)$. But, it is seen there is a significant difference post-test scores $(p=0.013<0.05)$. The experimental group points are significantly higher than the control group points. In this case, it can be concluded the creative dance is significantly effective on the success in analyzing the fugue form.

It is thought this result has been derived from the prospective music teachers have felt the fugue form with their bodies and sense organs. 


\section{Conclusions}

The creative dance has a facilitative effect on the analysis of fugue. This result has shown creative dance can be used as a learning approach. It can connect different disciplines each other and make learning permanent.

It can be benefited from creative dance, especially in theoretical courses such as Musical Forms teaching of certain subjects at intervals.

\section{References}

1. Akgül, K. P. İletişim, DansveBedenDili, İstanbul: CiniusYayınları, (2014).

2. Cangal, N. Müzik Formları, Ankara: Arkadaş Yayınevi, (2004).

3. Karasar, N. Bilimsel Araştırma Yöntemi, Ankara: Nobel Yayınevi, (2004).

4. Karkın, A.M., Kılıç, I. The Importance of Play, Dance and Music Course in terms of Teaching Music, Kastamonu Education Journal, 19/1, 103-112, (2011).

5. Kasap, D. The Analys of Johann Sebastian Bach's 24 Füg'es Performance, Edirne, Trakya University, Unpublished master's thesis, (2008).

6. Kaya, D. The Study of Johann Sebastian Bach's "The Art of Fugue" According to the Music Comprehension of the Baroque Period, Adana, Çukurova University, Unpublished master's thesis, (2009).

7. Özevin, B, Bilen, S. The Effects of Creative Dancing Activities on Motivation, Selfesteem, Self-efficacy and Dancing Performance, Hacettepe University Journal of Education 40:363-374, (2011).

8. Özevin, B, Bilen, S. Yaratıcı Dans, Ankara: Müzik Eğitimi Yayınları, (2011).

9. Özevin, B. Oyun, DansveMüzikDersineİlişkinMotivasyonÖlçeği, Denizli, Pamukkale Üniversitesi Eğitim Fakültesi, Ulusal Müzik Eğitimi Sempozyumu Bildirisi, (2006).

10. Preston-Dunlop, V. Dancing and Dance Theory, England: A Laban Centenary Publication, (1979).

11. Preston-Dunlop, V. A Handbook for Dance in Education, (2ndEdition). England: Macdonald and Evans, (1984).

12. Preston-Dunlop, V. Dance is a Language, isn't it?,England: Laban Center for Movement and Dance at University of London, (1992).

13. Robinson, K. Yaratıcılık: Aklın Sınırlarını Aşmak, (2. Basım). İstanbul: KitapYayınevi, (2008).

14. Sevgi, A. An Harmony Education as a Requirement of The Profession of Music Teaching, Gazi University Journal of Gazi Educational Faculty, 25/1, 199-211, (2005).

15. Smith-Autard, J. M. The Art of Dance in Education, (2ndEdition). Londra: A\&C Black, (2002).

16. Yıldırım, A. ,Şimşek, H. Sosyal Bilimlerde Nitel Araştırma Yöntemleri, (8.Basım). Ankara: SeçkinYayıncılık, (2011). 


\section{Appendix A.}

A. 1. Pictures from creative dance activities performed by experimental group
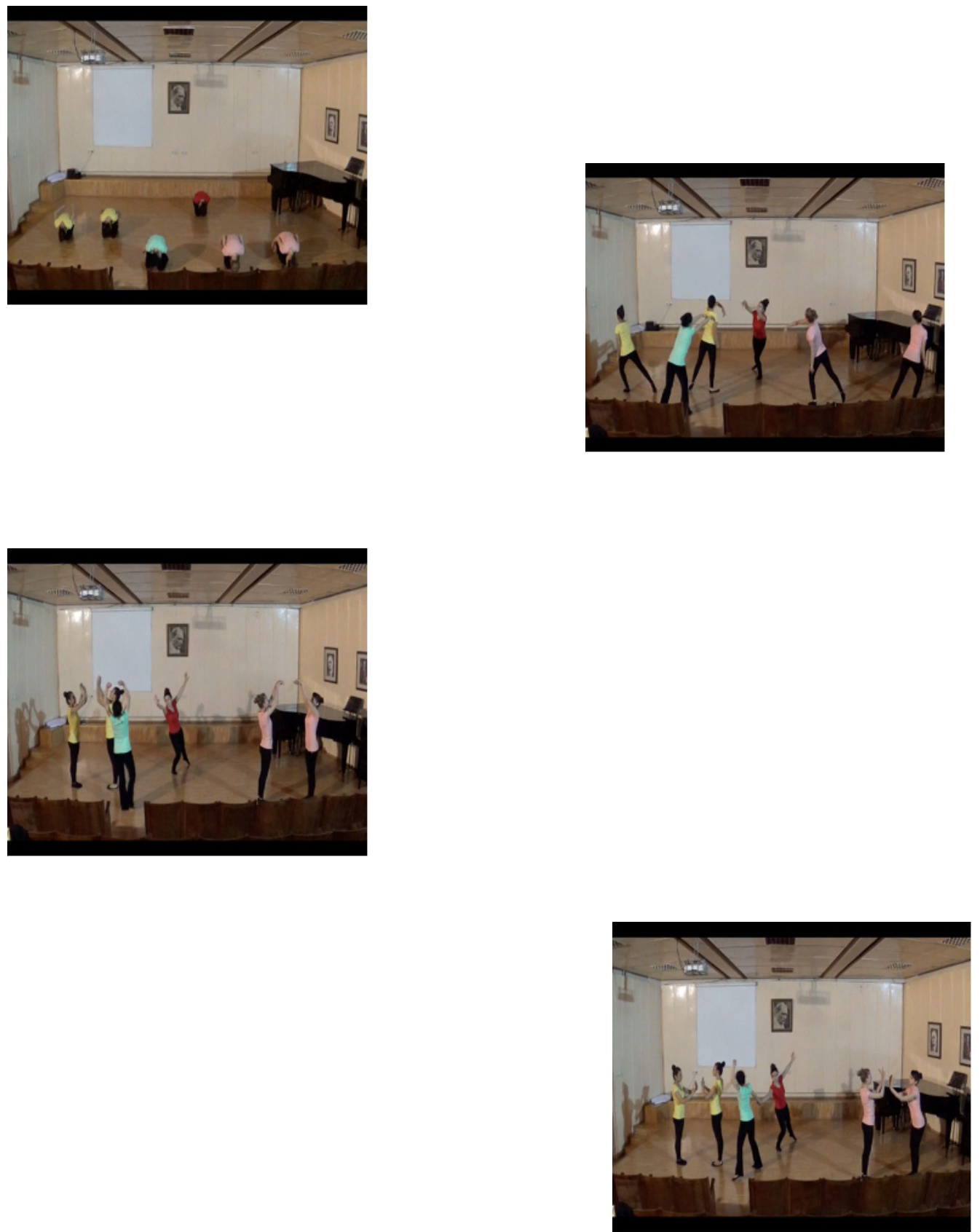